\title{
Molecular identity and cytotoxicity of Lenzites quercina macrofungus extracts toward cancer cell lines
}

\author{
Olusola Clement OGidi ${ }^{1 *}$, Victor Olusegun Oyetayo ${ }^{1}$, Bamidele Juliet AKinyele ${ }^{1}$, \\ OMONIKE OLUYEMISI OGBOLE ${ }^{2}$, JOHNSON ADEKUNLE ADENIJI ${ }^{3}$, BOLAJI BOSEDE OLUREMI ${ }^{4}$ \\ ${ }^{1}$ Department of Microbiology, Federal University of Technology, Akure, Nigeria \\ ${ }^{2}$ Department of Pharmacognosy, Faculty of Pharmacy, University of Ibadan, Ibadan, Nigeria \\ ${ }^{3}$ W.H.O. Polio Laboratory, Department of Virology, College of Medicine, University of Ibadan, Ibadan, Nigeria \\ ${ }^{4}$ Department of Pharmaceutical Microbiology, University of Ibadan, Ibadan, Nigeria
}

\begin{abstract}
The medicinal uses of wild macrofungi have been attributed to their accumulated bioactive compounds. Several mushrooms have been reported to possess antitumor activity, but little, in this regard, is known about Lenzites quercina collected from Akure in Nigeria. Hence, the molecular identification and cytotoxic activity of extracts obtained from raw and fermented Lenzites quercina were assessed. The macrofungus Lenzites quercina was identified using Internal Transcribed Spacers (ITS) sequence analysis. The basic local alignment search tool (BLAST) analyzed on NCBI GenBank data revealed that the Lenzites species from Nigeria - accession number, JF689829.1 - was closely related to Lenzites quercina (a 100\% relationship match). The cytotoxic activity of raw and fermented Lenzites quercina extracts was tested against human cervical cancer (HeLa), rhabdomyosarcoma (RD) and African green monkey kidney (VERO) cell lines. A tetrazolium yellow 3-(4,5-dimethyl thiazol-2-yl)-2,5diphenyl tetrazolium bromide (MTT) colorimetric assay was used to evaluate the reduction in viability of cell cultures with or without the extracts of Lenzites quercina. Extracts of Lenzites quercina exhibited cytotoxic activity (6.0-84.5\%) against the tested cancer cell lines (HeLa, VERO and RD). The concentration of the bioactive compounds in the crude extract ranged from 0.01 to $1000 \mu \mathrm{g} / \mathrm{ml}$. The results revealed that bioactive compounds in Lenzites quercina possess cytotoxic properties. These bioactive compounds may be isolated and used as alternative therapies to currently available anticancer drugs.
\end{abstract}

Key words: Lenzites quercina, chemotherapy, cancer cells, MTT

\section{Introduction}

Macrofungi are known to contain secondary metabolites, which possess biological activities. The presence of these biomolecules in wild mushrooms has stimulated their potential utilization for biotechnological and medicinal purposes, as well as environmental applications (Ruthes et al., 2016). Most of the bioactive compounds in medicinal mushrooms are responsible for their antioxidant, antibacterial, antifungal, antiviral, immunomodulatory/immunostimulatory, anti-hypertensive and blood lipid level lowering effects. The medicinal potential of wild macrofungi has been adequately exploited for the production of specific drugs in developing countries (Badalyan, 2014).
In spite of the large number of wild macrofungi, many of them are still underutilized, especially those growing in Africa. This may be caused by problems in systemic taxonomy, improper identification and some other nomenclature challenges. Most species of mushroom previously described by morphological characteristics differ from their taxa or genera (Hyde et al., 2013). Researchers should not allow this chaos of nomenclature to dissuade them from their interest in the uses of mushrooms, since mushrooms possess various therapeutic characteristics that are important to users.

Chemotherapy, radiotherapy and surgery are the most common treatments for cancers, but several side effects such as fatigue, nausea, vomiting, malaise, diar-

\footnotetext{
${ }^{*}$ Corresponding author: Federal University of Technology Akure, P.M.B. 704, Akure, Ondo State, Nigeria; e-mail: clementogidi@yahoo.com
} 
rhea, mucositis, pain, rashes, infections, headaches occur during treatment (Sak, 2012). Ma et al. (2009) revealed that the use of chemotherapeutic alkylating agents (cyclophosphamide, ifosfamide) and topoisomerase II inhibitors increases the risk of secondary cancer development (acute leukemia). Anthracyclines induce cardiotoxicity, while cisplatin induces nephrotoxicity; a potential cause of peripheral nerve damage and renal impairment with a decline in glomerular filtration (Sak, 2012). The failure displayed by some chemotherapies during the treatment of cancers, and the cost of drugs and treatment has become a public health concern. Therefore, alternative and effective anticancer therapies should derive from natural products which may decrease the adverse action of conventional methods and reduce the cumulative side effects of chemotherapies.

Bioactive natural compounds from wild medicinal mushrooms can be extracted, improved and used as reliable and efficient chemotherapeutic agents to combat the failure of chemotherapeutic drugs. This approach could relieve the adverse side effects associated with drugs used for cancer treatment. Some wild mushrooms, such as Pleurotus spp., Agaricus blazei, Ganoderma lucidum, Clitocybe nebularis, Trametes spp., Piptoporus betulinus, Inocybe umbrinella, Coprinus comatus, Fomes fomentarius, Lactarius flavidulus, Albatrellus confluens, Cordyceps sinensis, Schizophyllum commune, and Inonotus obliquus, have been credited with anticancer activity due to the presence of bioactive compounds (Patel and Goyal, 2012). Several pharmaceutical products formulated from medicinal mushrooms, such as krestin, lentinane, coriolan or schizophyllan, are already available on the world market (Badalyan, 2014). Krestin (Polyssacharide K or PSK) isolated from the fruit body of Trametes versicolor has shown in vitro and in vivo anticancer activity in human clinical trials (Jiménez-Medina et al., 2008; Yamasaki et al., 2009). Lentinan, an antitumor polysaccharide isolated from the fruit body of Lentinula edodes (shiitake) has been approved as an adjuvant for stomach cancer in Japan since 1985, and is one of the host-mediated anticancer drugs shown to affect host defense immune systems (Sia and Candlish, 1999).

To date, little is known about the cytotoxicity potential of Lenzites quercina extracts against cancer cells. This study, therefore, provides information on the molecular identity and anticancer activities of extracts obtained from raw and fermented Lenzites quercina.

\section{Materials and methods}

\section{Collection of mushroom}

The fruit body of Lenzites quercina were collected from a farmland near the Federal University of Technology, Akure, Nigeria $\left(07^{\circ} 14^{\prime} \mathrm{N}, 05^{\circ} 11^{\prime} \mathrm{E}\right)$ during the month of November, 2012. The mushroom fruit body was dried and maintained in a desiccator until needed for use. A voucher specimen was also kept in the Department of Microbiology, Federal University of Technology, Akure (FUTA), Nigeria.

\section{Extraction of DNA from mushroom sample}

The standard DNA isolation method described by Zolan and Pukkila (1986) was employed. Briefly, dried portions of Lenzites quercina fruit body ( $2 \mathrm{~g}$ ) was ground with a mortar and pestle. The ground material was transferred into clearly labeled microtubes. Ten milliliters $(10 \mathrm{ml})$ of pre-warmed $\left(60^{\circ} \mathrm{C}\right)$ extraction buffer, $2 \% \mathrm{w} / \mathrm{v}$ of cetyltrimethylammonium bromide (CTAB) diluted in $100 \mathrm{mM}$ Tris- $\mathrm{HCl}, 20 \mathrm{mM}$ EDTA, $1.4 \mathrm{M}$ of $\mathrm{NaCl}$ and $\beta$-mercaptoethanol $(2 \% \mathrm{v} / \mathrm{v})$, was added and the tubes were incubated at $65^{\circ} \mathrm{C}$ for $60 \mathrm{~min}$. Ten milliliters $(10 \mathrm{ml})$ of chloroform and isoamyl alcohol $(24: 1)$ was added and mixed by inverting tubes for $15 \mathrm{~min}$. The tubes were centrifuged for $10 \mathrm{~min}$ at $10000 \mathrm{~g}$. The process was repeated and the samples were centrifuged for $5 \mathrm{~min}$ at $10000 \mathrm{~g}$. Upper aqueous layers were transferred into clean tubes and $40 \mu \mathrm{l}$ sodium acetate $(\mathrm{NaAc})$ at pH 5.0 was added to each tube followed by $260 \mu 1$ of cold isopropanol. The solutions were gently mixed by inverting the tubes, and then incubated at $-20^{\circ} \mathrm{C}$ overnight. On the second day, the mixtures were centrifuged for $10 \mathrm{~min}$ at $10000 \mathrm{~g}$. The supernatants were discarded and pellets rinsed with $70 \%$ ethanol and mixed. This procedure was repeated three times. After discarding the supernatants, the samples were dried in a dryer for $20 \mathrm{~min}$ at room temperature. Pellets were re-suspended in $30 \mu \mathrm{l}$ of Tris EDTA (TE) buffer. The quality of DNA was analyzed on an ethidium-stained agarose gel (0.7\%) using $0.2 \mu \mathrm{l}$ of each sample.

\section{PCR amplification of the ITS region}

The entire region of the rDNA of Lenzites quercina (670 nt) was amplified by PCR using ITS4 and ITS5 primers. The reaction mix was made up of a total volume of $25 \mu \mathrm{l}$, composed of $23 \mu \mathrm{l}$ of Taq polymerase "Ready to 
Go" mixture (Pharmacia, Sweden) with $0.2 \mu \mathrm{l}$ of each primer $(100 \mathrm{pM})$ and $2 \mu \mathrm{l}$ of DNA solution. The tubes were placed in a thermal cycler (GenAmp PCR System 2400, Perkin-Elmer, USA) for amplification under the following conditions: 30 cycles of (1) denaturation at $95^{\circ} \mathrm{C}$ for $30 \mathrm{~s}$; (2) annealing at $50^{\circ} \mathrm{C}$ for $1 \mathrm{~min}$; and (3) extension at $72^{\circ} \mathrm{C}$ for $1 \mathrm{~min}$. The amplification products were purified using a PCR Purification Kit (USA) and electrophoresed on ethidium-stained agarose gel (0.7\%) to check the purity. DNA sequencing was performed using the same primer pair as used previously (ITS 4 and ITS 5) in an Applied Biosystem DNA Analyzer (USA).

\section{Sequence alignment}

Alignments were performed with the Clustal W package (Thompson et al., 1997). The aligned sequences were corrected manually and through focusing on gap positions. DNA sequence data were analyzed to provide pairwise percentage sequence divergence. The data obtained from the sequence alignment were used to plot a tree diagram using Molecular Evolutionary Genetics Analysis (MEGA 4 Software). The bootstraps varied from 75 to 100. The Neighbor Joining (NJ) method was used.

\section{Preparation of Lenzites quercina extracts}

After drying, sample of Lenzites quercina was divided into two equal portions (500 g): a) unfermented; while the other part, b) was subjected to solid statefermentation for 4 days at room temperature $\left(26 \pm 2^{\circ} \mathrm{C}\right)$ to release the phenolic compounds bound in the mushroom cell wall. The fermented portion of Lenzites quercina was then dried in an oven (DHG9053-A) at $30^{\circ} \mathrm{C}$. Well dried samples were ground into powder using a mill machine (Retsch GmbH 5657 HAAN). The unfermented and fermented powders of Lenzites quercina (100 g each) were sequentially extracted with different solvents of the same volume as follows: petroleum ether $(1000 \mathrm{ml}$ of $95 \% \mathrm{v} / \mathrm{v}$ ), ethyl acetate and ethanol. Each mushroom portion was soaked in a solvent for 72 hours and filtered with Whatman filter paper No 1 . The filtrates obtained were concentrated in a rotary evaporator (RE-52A, UNION Laboratories, England), freeze dried and kept in a refrigerator at $4^{\circ} \mathrm{C}$. The extracts were coded as RPP - raw Lenzites quercina extracted with petroleum ether, REA - raw Lenzites quercina extract obtained with ethyl acetate, RET - raw Lenzites quercina extract obtained with ethanol, FPP - fermented Lenzites quercina extract obtained with petroleum ether, FEA - fermented Lenzites quercina extract obtained with ethyl acetate, and FET - fermented Lenzites quercina extract obtained with ethanol. Each extract (20 mg) was reconstituted in $2 \mathrm{ml}$ of dimethyl sulfoxide (DMSO) and centrifuged at $10000 \mathrm{~g}$ for $5 \mathrm{~min}$ in $4^{\circ} \mathrm{C}$.

\section{Preparation of cell lines}

The rhabdomyosarcoma (RD), human cervical cancer (HeLa) and African green monkey kidney (VERO) cancer cell lines were obtained from the Department of Virology, College of Medicine, University of Ibadan, Nigeria.

Cells were grown in a minimum essential medium supplemented with $10 \%$ fetal bovine serum and penicillin-streptomycin-glutamine (100X, 10,000 U of penicillin, $10 \mathrm{mg}$ of streptomycin and $29.2 \mathrm{mg} / \mathrm{ml}$ of L-glutamine in a $10 \mathrm{mM}$ citrate buffer) and cultured in a humidified atmosphere of $5 \% \mathrm{CO}_{2}$ and $95 \%$ air at $37^{\circ} \mathrm{C}$ in a Forma Scientific incubator. Cells were seeded in 96well culture plates. The plates were then incubated in a humidified atmosphere with $5 \% \mathrm{CO}_{2}, 95 \%$ air and $37^{\circ} \mathrm{C}$ for $24 \mathrm{~h}$ to obtain a confluent monolayer of cell culture.

\section{Determination of the cytotoxicity of Lenzites quercina extracts by MTT colorimetric assay}

The cytotoxic potential of Lenzites quercina extracts was evaluated using an MTT colorimetric assay according to the method described by Mossmann (1983). Briefly, each extract $(10 \mathrm{mg} / \mathrm{ml})$ was serially diluted tenfold with a maintenance medium to give varying concentrations of 0.01 to $1000 \mu \mathrm{g} / \mathrm{ml}$. Each concentration was then transferred into 96-well plates previously seeded with monolayers of each confluent cell line. The plates were incubated at $37^{\circ} \mathrm{C}$ in $5 \% \mathrm{CO}_{2}$ humidified incubator for $72 \mathrm{~h}$. Plates were observed under the microscope for normal cell morphology, cell density, cell death in the presence of mushroom extracts and compared to control cells grown without the extracts. The medium was gently removed and $25 \mu \mathrm{l}$ of MTT, dissolved in PBS solution $(2 \mathrm{mg} / \mathrm{ml})$, was added to each well and incubated for $2 \mathrm{~h}$ at $37^{\circ} \mathrm{C}$. The MTT solution was removed from the wells and $125 \mu \mathrm{l}$ of dimethyl sulfoxide (DMSO) was added to dissolve the insoluble formazan crystals resulting from MTT reduction, plates were then gently sha- 


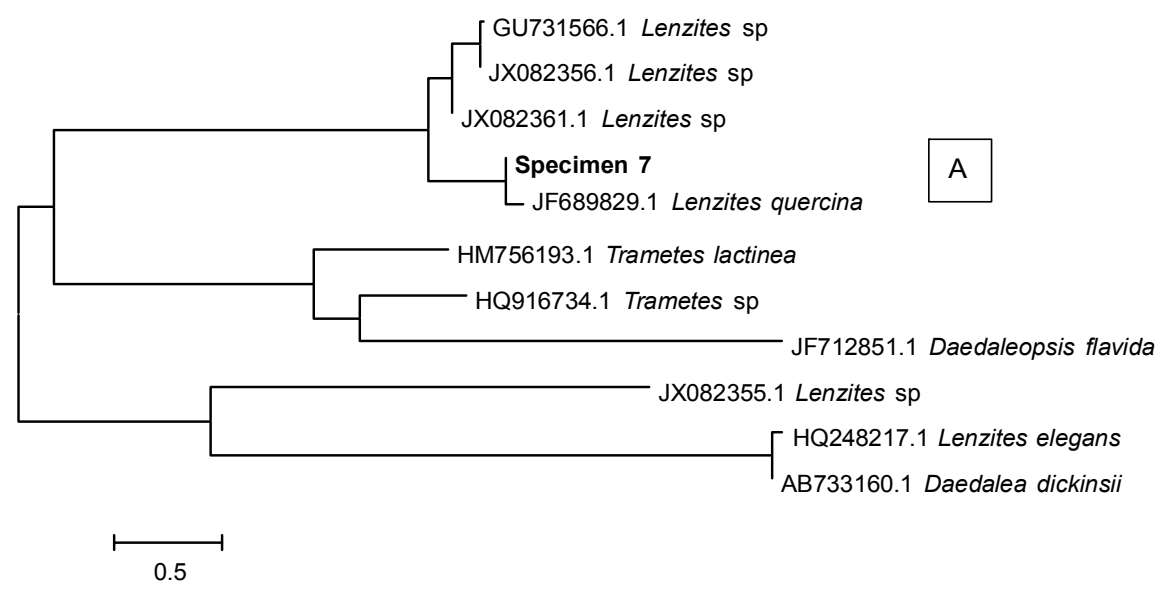

Fig. 1. Phylogenetic tree of Lenzites quercina (specimen 7) related to an existing sequence obtained from NCBI GenBank
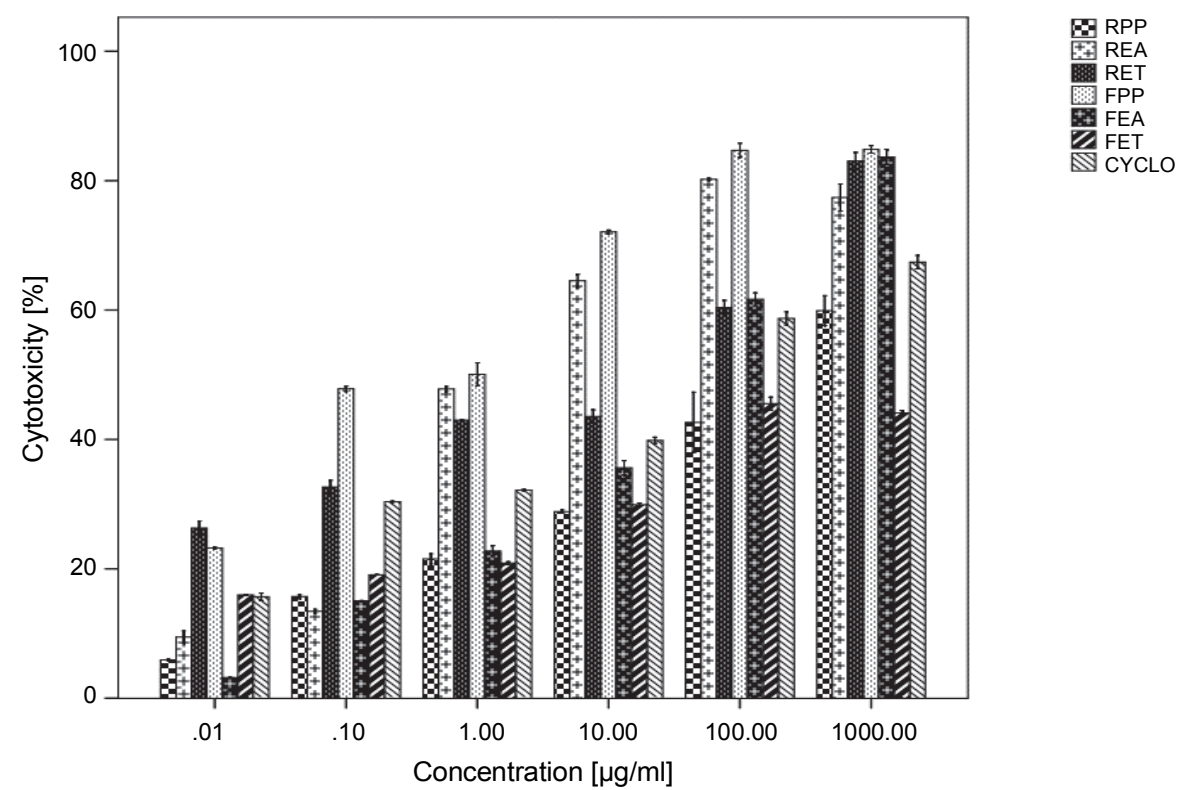

Fig. 2. Cytotoxicity of raw and fermented extracts of Lenzites quercina against HeLa RPP - raw Lenzites quercina extracted with petroleum ether, REA - raw Lenzites quercina extracted with ethyl acetate, RET - raw Lenzites quercina extracted with ethanol, FPP - fermented Lenzites quercina extracted with petroleum ether, FEA - fermented Lenzites quercina extracted with ethyl acetate, FET - fermented Lenzites quercina extracted with ethanol, CYCLO - cyclophosphamide

ken. The optical density of the wells was measured using a spectrophotometer (Emax Precision Microplate Reader) at $490 \mathrm{~nm}$. Data obtained from triplicate wells were used to determine the percentage of cytotoxicity, calculated as:

$$
\% \text { cytotoxicity }=[(\mathrm{A}-\mathrm{B}) / \mathrm{A}] \times 100
$$

where, $A$ is the optical density of untreated wells and B is the optical density of wells with extracts or cyclophosphamide as a positive control.

\section{Statistical analysis}

Each experiment was replicated three times. Data obtained were subjected to analysis of variance (ANOVA) using SPSS version 21. The $\mathrm{CC}_{50}$, the concentration required to kill $50 \%$ of the cell population, was determined from the dose-response curves. The selectivity index was calculated as: $\mathrm{SI}=\mathrm{CC}_{50}$ of extracts against African green monkey kidney cell line (VERO)/ $\mathrm{CC}_{50}$ of the same extract in a cancer cell line, where $\mathrm{CC}_{50}$ is the concentration required to kill $50 \%$ of the cell population. 

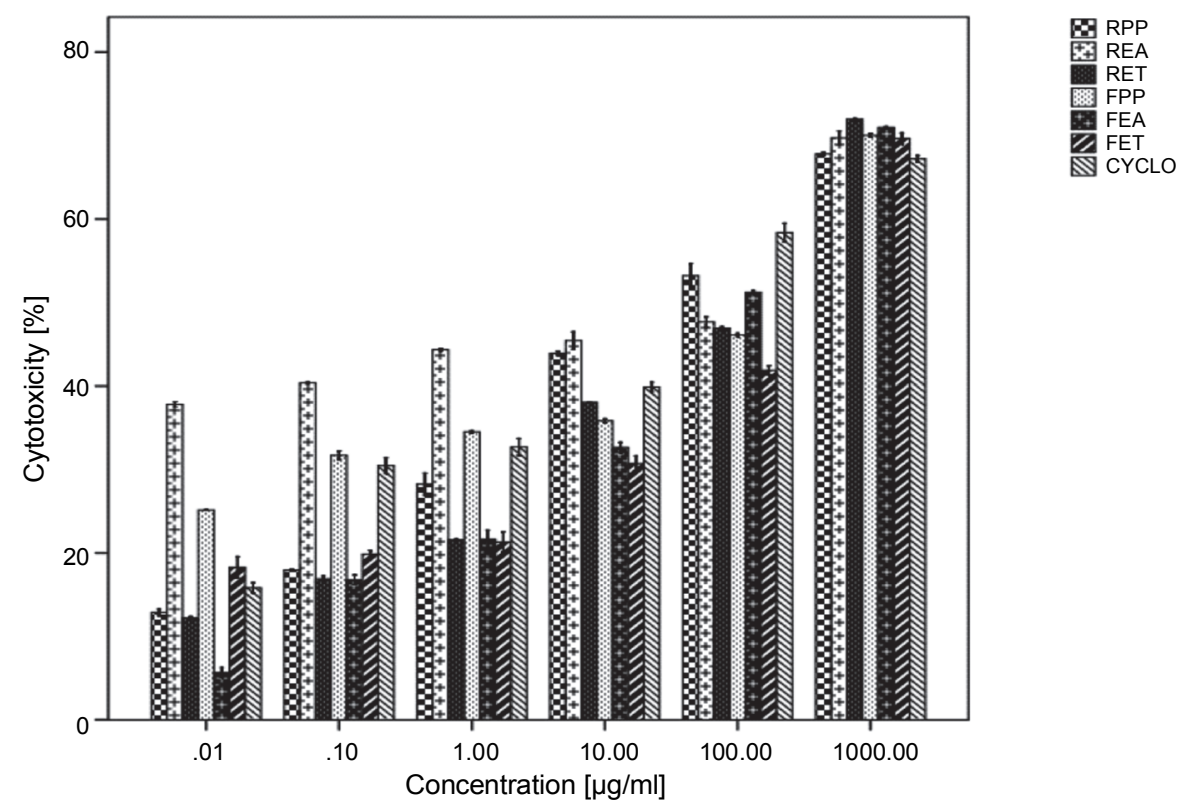

Fig. 3. Cytotoxicity of raw and fermented extracts of Lenzites quercina against VERO RPP - raw Lenzites quercina extracted with petroleum ether, REA - raw Lenzites quercina extracted with ethyl acetate, RET - raw Lenzites quercina extracted with ethanol, FPP - fermented Lenzites quercina extracted with petroleum ether, FEA - fermented Lenzites quercina extracted with ethyl acetate, FET - fermented Lenzites quercina extracted with ethanol, CYCLO - cyclophosphamide
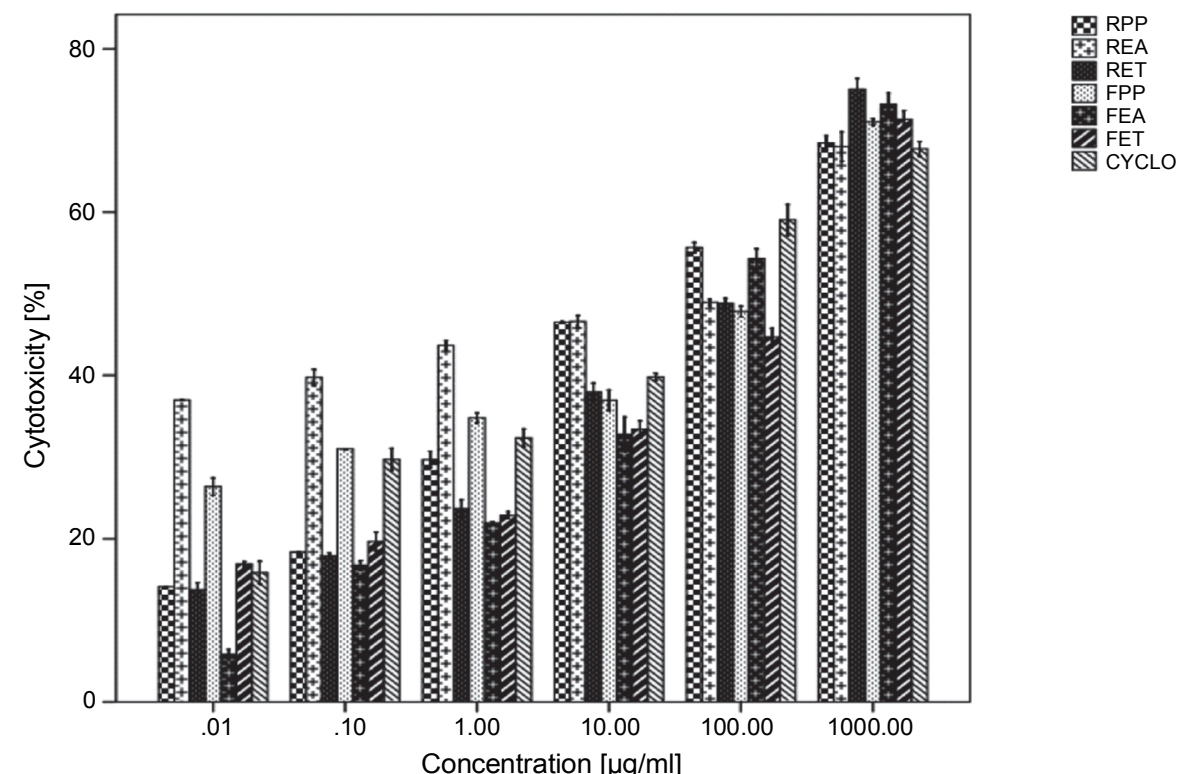

Fig. 4. Cytotoxicity of raw and fermented extracts of Lenzites quercina against RD RPP - raw Lenzites quercina extracted with petroleum ether, REA - raw Lenzites quercina extracted with ethyl acetate, RET - raw Lenzites quercina extracted with ethanol, FPP - fermented Lenzites quercina extracted with petroleum ether, FEA - fermented Lenzites quercina extracted with ethyl acetate, FET - fermented Lenzites quercina extracted with ethanol, CYCLO - cyclophosphamide 


\section{Results and discussion}

The use of fruit body morphology, such as the appearance, color, dimension, spores and form of the fungus on media, with other physiological parameters and environmental growth preferences can sometimes confuse the identification of macrofungi without the use of microscopic examination and molecular tools (Hood, 2006). Therefore, proper identification of wild medicinal and edible mushrooms is necessary for their documentation and effective exploration. Molecular identification using the internal transcribed spacer (ITS) sequence reveals the identity of the macrofungus collected from Akure, Southwest, Nigeria. Basic local alignment sequence tool (BLAST) analysis showed that the ITS sequence of Lenzites quercina denoted specimen 7 matched Lenzites quercina with accession number, JF689829.1, from the NCBI GenBank (Fig. 1). Das et al. (2013) stated that sequencing of repetitive nuclear DNA of mushrooms is a powerful tool for identification purposes and phylogenetic studies. The ITS and large subunit (LSU) of rDNA are the genomic regions used to identify and phylogenetically analyze fungi to species level (Porras-Alfaro et al., 2014). Such DNA sequences are currently used to resolve taxonomic problems; therefore, it is safe to say that the molecular approach has helped to detect the origins of medicinal mushrooms and solve some taxonomic challenges (Hyde et al., 2013).

The presence of phytoconstituents in many wild medicinal mushrooms confers therapeutic abilities that can be adopted as adjuvant therapy (Badalyan, 2014). Therefore, natural products isolated from medicinal mushrooms could play a significant role in cancer and other disease therapies. The phytochemical constituents and bioactive compounds in the extracts of Lenzites quercina were analyzed and reported in Ogidi et al. (2015). The above-mentioned study revealed the presence and quantity of the following phytochemicals: alkaloids, saponins, flavonoids, tannin, steroids, anthraquinones, terpenoids, and cardiac glycosides. The compounds identified using GC/MS were caprylic acid, n-decanoic acid, dodecanoic acid, Phosphoric acid tributyl ester, tetradecanoic acid, stearic acid, methyl-11-octadecanoate, oleic acid and 4-methyl-2-propyl-1-pentanol. These bioactive compounds are known to possess nutraceutical properties such as antimicrobial, anticancer and antioxidant properties (Ferreira et al., 2010; Wasser, 2011).
The cytotoxic activity of the extracts from raw (unfermented) and fermented Lenzites quercina against the tested cancer cell lines - HeLa, VERO and RD, are shown in Figures 2, 3 and 4. It was observed that the inhibitory action of extracts against cancer cell lines was concentration dependent. An extract from fermented Lenzites quercina obtained using petroleum ether (FPP) displayed the highest cytotoxicity (84.50\%) against HeLa (Fig. 2). An extract obtained from raw Lenzites quercina using ethyl acetate (REA), ethanolic extract from raw Lenzites quercina (RET), FPP and an extract from fermented Lenzites quercina obtained using ethyl acetate (FEA) exhibited higher percentages of cytotoxicity, ranging from 69.1 to $84.50 \%$ against HeLa and VERO when compared $(P<0.05)$ to the activity of cyclophosphamide $(67.10 \%)$ at $1000 \mu \mathrm{g} / \mathrm{ml}$. Raw Lenzites quercina extracted with ethanol (RET) exhibited $71.90 \%$ and $74.60 \%$ of cytotoxicity against VERO and $\mathrm{RD}$ at $1000 \mu \mathrm{g} / \mathrm{ml}$, as shown in Figures 3 and 4, respectively. The cytotoxicity observed in wild macrofungus extracts and the positive control (cyclophosphamide) at $1000 \mu \mathrm{g} / \mathrm{ml}$ against $\mathrm{RD}$ were not significantly different at $(P<0.05)$. Table 1 reveals the cytotoxic concentration of various extracts that killed (50\%) and their selective indices against the HeLa and RD. Vanyolos et al. (2015) reported the anticancer activity of some higher mushrooms (growing in Hungary) against human cancer cell lines using a similar assay with 3-(4,5-dimethylthiazol-2-yl)-2,5-diphenyltetrazolium bromide. Wasser (2011) also stated that more than 30 species of medicinal mushrooms had been scientifically proven to have antitumor activity in experimental studies. The anticancer activity of wild medicinal mushrooms has been linked to the presence of $\beta$-glucan, phytochemicals, saponins, alkaloids and phenolic compounds, which are capable of interfering with particular cellular signal transduction pathways linked to cancer development and progression (De Silva et al., 2012; Lavi et al., 2012). Daba and Ezeronye (2003) revealed that polysaccharides present in the extracts from higher Basidiomycetes (mushrooms) displayed anticancer activities by suppressing cell proliferation and subsequently inducing cellular apoptosis, which gave cells their physiological balance and, therefore, played a critical role as a protective mechanism against carcinogenesis via elimination of damaged or abnormal excess proliferating cells (Hengartner, 2000). Tsay et al. (2009) also demonstra- 
Table 1. Cytotoxic concentration (50\%) of various extracts and their respective selective index (SI)

\begin{tabular}{l|c|c|c|c|c}
\hline \multirow{2}{*}{ Extracts } & \multicolumn{3}{|c|}{$\mathrm{CC}_{50}(\mu \mathrm{g} / \mathrm{ml})$} & \multicolumn{2}{c}{ SI } \\
\cline { 2 - 6 } & HeLa & RD & VERO & HeLa & RD \\
\hline RPP & 0.28 & 4.85 & 257.6 & 0.0010 & 0.0188 \\
\hline REA & 0.11 & 18.57 & 623.0 & 0.0001 & 0.0298 \\
\hline RET & 0.81 & 9.24 & 7.36 & 0.1100 & 1.2555 \\
\hline FPP & 3.32 & 0.79 & 5.80 & 0.5724 & 0.1362 \\
\hline FEA & 1.26 & 16.78 & 1.42 & 0.8873 & 11.8169 \\
\hline FET & 0.71 & 0.46 & 0.64 & 1.1093 & 0.7187 \\
\hline Cyclophosphamide & 0.62 & 0.62 & 0.62 & 1.000 & 1.0000 \\
\hline
\end{tabular}

$\mathrm{CC}_{50}-50 \%$ cytotoxic concentration, SI - selectivity index, RPP - raw Lenzites quercina extracted with petroleum ether, REA - raw Lenzites quercina extracted with ethyl acetate, RET - raw Lenzites quercina extracted with ethanol, FPP - fermented Lenzites quercina extracted with petroleum ether, FEA - fermented Lenzites quercina extracted with ethyl acetate, FET - fermented Lenzites quercina extracted with ethanol, $\mathrm{RD}$ - rhabdomyosarcoma cell, HeLa - human cervical cancer cell, VERO - African green monkey kidney cell line

ted that the protein extracts obtained from Calvatia lilacina induced apoptosis through glutathione (GSH) depletion in SW480 human colorectal cancer cells. Moreover, an extract from Pleurotus ostreatus suppressed the proliferation of breast and colon cancer cells via p53dependent and p53-independent pathways (Jedinak and Sliva, 2008). The cytotoxicity displayed by Lenzites quercina extracts against cancer cell lines revealed that untapped wild macrofungi should be investigated for their cytotoxic properties and be potentially used for anticancer therapy.

In conclusion, the bioactive compounds in extracts of Lenzites quercina displayed significant anticancer effects in vitro, which could be developed and used as an alternative to synthetic drugs.

\section{Acknowledgements}

The authors appreciate the technical support received from the Institute of Microbiology, Chinese Academy of Science (IMCAS), China and University College Hospital (UCH), Ibadan, Nigeria.

\section{References}

Badalyan S.M. (2014) Potential of mushroom bioactive molecules to develop healthcare biotech products, Proceedings of the 8th International Conference on Mushroom Biology and Mushroom Products (ICMBMP8). New Delhi, India.

Daba A.S., Ezeronye O.U. (2003) Anti-cancer effect of polysaccharides isolated from higher Basidiomycetes mushrooms. Afr. J. Biotech. 2(12): 672-678.

Das S.K., Mandal A., Datta A.K., Gupta S., Paul R., Saha A., Sengupta S., Dubey P.K. (2013) Nucleotide Sequencing and Identification of Some Wild Mushrooms. Sci, World J. 2013: 1-7. http://dx.doi.org/10.1155/2013/403191.

De Silva D.D., Rapior S., Fons F., Bahkali A.H., Hyde K.D. (2012) Medicinal mushrooms in supportive cancer therapies: an approach to anti-cancer effects and putative mechanisms of action. Fungal Diver. 55: 1-35.

Ferreira I.C., Vaz J.A., Vasconcelos M.H., Martins A. (2010) Compounds from wild mushrooms with antitumor potential. Anticancer Agents Med. Chem. 10(5): 424-436.

Hengartner M.O. (2000) The biochemistry of apoptosis. Nat. 407: 770-776.

Hood I.A. (2006) The Mycology of the Basidiomycetes. [in:] Heart rot and root rot in Tropical Acacia Plantations. Proceedings of a Workshop held in Yogyakarta, Indonesia, 7-9 February 2006. Australian Center for International Agricultural Research (ACIAR) Proceedings, Canberra, 124: 34-59.

Hyde K.D., Udayanga D., Manamgoda D.S., Tedersoo L., Larsson E., Abarenkov K., Bertrand Y.J.K., Oxelman B., Hartmann M., Kauserud H., Ryberg M., Kristiansson E., Nilsson R.H. (2013) Incorporating molecular data in fungal systematics: a guide for aspiring researchers. Curr. Res. Environ. Appl. Mycol. 3(1): 1-32. Doi: 10.5943/cream/3/1/1.

Jedinak A.J., Sliva D. (2008) Pleurotus ostreatus inhibits proliferation of human breast and colon cancer cells through p53-dependent as well as p53-independent pathway. Int. J. Oncol. 33: 1307-1313.

Jiménez-Medina E., Berruguilla E., Romero I. et al. (2008) The immunomodulator PSK induces in vitro cytotoxic activity in tumor cell lines via arrest of cell cycle and induction of apoptosis. BMC Cancer 8: 78-87.

Lavi I., Nimri L., Levinson D., Peri I., Hadar Y., Schwartz B. (2012) Glucans from the edible mushroom Pleurotus pulmonarius inhibit colitis-associated colon carcinogenesis in mice. J. Gastroenterol. 47: 504-518. 
Ma H., Das T., Pereira S., Yang Z., Zhao M., Mukerji P., Hoffman R.M. (2009) Efficacy of dietary antioxidants combined with a chemotherapeutic agent on human colon cancer progression in a fluorescent orthotopic mouse model. Anticancer Res. 29: 2421-2426.

Mossman T. (1983) Rapid colorimetric assay for cellular growth and survival: application to proliferation and cytotoxicity assays. J. Immunol. Meth. 65: 55-63.

Patel S., Goyal A. (2012) Recent developments in mushrooms as anti-cancer therapeutics: a review. 3 Biotech. 2: 1-15. Doi: 10.1007/s13205-011-0036-2.

Porras-Alfaro A., Liu K.-L., Kuske C.R., Xie G. (2014) From genus to phylum: large-subunit and Internal Transcribed Spacer rRNA operon regions show similar classification accuracies influenced by database composition. Appl. Environ. Microbiol. 80(3): 829-840.

Ruthes A.C., Smiderlea F.R., Iacominia M. (2016) Mushroom heteropolysaccharides: a review on their sources, structure and biological effects. Carbohy. Poly. 136: 358-375. http://dx.doi.org/10.1016/j.carbpol.2015.08.061.

Sak K. (2012) Chemotherapy and dietary phytochemical agents. Chemo. Res. Prac. 2012: 1-11. doi: 10.1155/ $2012 / 282570$.

Sia G.M., Candlish J.K. (1999). Effects of shiitake (Lentinus edodes) extract on human neutrophils and the U937 monocytic cell line. Phytother. Res. 13(2): 133-137.
Thomson J.D., Gibson T.J., Plewniak F., Jeanmougin F., Higgins D.G. (1997). The Clustal_X windows interface: flexible strategies for multiple sequence alignment aided by quality analysis tools. Nucleic Acids Res. 25: 48764882.

Tsay J.G., Chung K.T., Yeh C.H., Chen W.L., Chen C.H., Lin M.H. (2009) Calvatia lilacina protein-extract induces apoptosis through glutathione depletion in human colorectal carcinoma cells. J. Agric. Food Chem. 57: 1579-1588.

Vanyolos A., Kovacs B., Bozsity N., Zupko I., Hohmann J. (2015) Antiproliferative activity of some higher mushrooms from Hungary against human cancer cell lines. Int. J. Med. Mushrooms. 17(12): 1145-1149.

Wasser S.P. (2014) Medicinal mushroom science: current perspectives, advances, evidences, and challenges. Biomed. J. 37(6): 345-356. Doi: 10.4103/2319-4170. 138318.

Wasser S.P. (2011) Current findings, future trends, and unsolved problems in studies of medicinal mushrooms. Appl. Microbiol. Biotech. 89: 1323-1332.

Yamasaki A., Shoda M., Iijima H. et al. (2009) A protein bound polysaccharide, PSK, enhances tumor suppression induced by docetaxel in a gastric cancer xenograft model. Anticancer Res. 29(3): 843-850.

Zolan M.E., Pukkila P.J. (1986) Inheritance of DNA methylation in Coprinus cinereus. Mol. Cell Biol. 6: 195-200. 